\title{
Rhétoriques de la déchéance royale chez Marlowe et Shakespeare
}

Jean Dubu

\section{(2) OpenEdition}

Journals

\section{Édition électronique}

URL : http://journals.openedition.org/shakespeare/1231

DOI : 10.4000/shakespeare.1231

ISSN : 2271-6424

Éditeur

Société Française Shakespeare

Édition imprimée

Date de publication : 1 novembre 1992

Pagination : 79-90

Référence électronique

Jean Dubu, «Rhétoriques de la déchéance royale chez Marlowe et Shakespeare », Actes des congrès de la Société française Shakespeare [En ligne], 10 | 1992, mis en ligne le 01 janvier 2007, consulté le 19 avril 2019. URL : http://journals.openedition.org/shakespeare/1231; DOI : 10.4000/shakespeare.1231

Ce document a été généré automatiquement le 19 avril 2019

(C) SFS 


\section{Rhétoriques de la déchéance royale chez Marlowe et Shakespeare}

Jean Dubu 